\title{
On the Subspecific Validity of Pyrrhula uchidai Kuroda of Formosa.
}

\author{
By \\ Nagamichi Kuroda, D. Sc.
}

With Plate I.

Marquis Yamashina has recently received 16 adult males, 11 adult females and 3 juvenile females of Pyrrhula whidai and 5 adult males, 5 adult females and 1 juvenile female of $P$. owstoni from Formosa, and has just published his paper(see, pp.1-6 of this number of "Tori," in Japanese)on the critical notes upon $P$. uchidai and $P$. owstoni of the mountains of Formosa, giving the decisive conclusion to distinguish between them.

His valuable conclusion leads that while $P$. uchidai is a valid subspecies of nipalensis, P. owstoni is a subspecies of erythaca, and Ogilvie-Grant's arizanica is a pure synonym of owstoni.

The reason of his conclusion is as follows:-

Messrs. Rothschild and Hartert's description: "Juv. Feathers of crown blackish, edges with light greyish-brown' (Bull. B. O. C., xxi, p. 10) is not a description of juvenile of owstoni, but an adult of uchidai ! And the late Mr. Ogilvie-Grant has erroneously compared his adult male of "arizanica" with an undescribed form (uchidai); the latter has been considered by him as a typical owstoni.

I am greatly indebted for the Marquis's re-examination about the two forms of the different species and I must express my sincere congratulation on his decisive conclusion of such a complicated and difficult problem.

At this opportunity I am going to add a few paragraphs about them.

\section{Pyrrhula erythaca owstoni.}

1907.-Pyrhula owstoni Rothschild \& Hartert. Bull. B. O. C., xxi, Oct. 29,1907, p. 9(Mt. Arizan, $f$ ad. with feebly reddish on sides of the breast).

1912.-Pyrrhula arizanica Ogilvie-Grant, Ibis, p. 644 (Mt. Arizan, of ad. 
with deeper reddish on the breast).

I have kept the following skins which are not included in Marquis Yamashina's paper. They measure as follows:

\begin{tabular}{|c|c|c|c|c|c|c|c|c|}
\hline No. & $\begin{array}{l}\text { Locality } \\
\text { Niitakazen- }\end{array}$ & Date & $\overline{\text { Sex }}$ & Wing & Tail & Tarsus & Exposed & Collector \\
\hline 4238 & zan & 9. iv. 1919 & sad. & 82 & 69.5 & 17 & 10.5 & Kikuchi \\
\hline *4239 & $"$ & $" \prime \prime$ & sad. & $8: 2$ & 70 & 18 & 10.5 & $"$ \\
\hline 4240 & $"$ & 2.2. $"$ & cad. & 80.5 & 67 & 18 & 10.5 & $"$ \\
\hline 4241 & $"$ & 23. " & $q$ ad. & 80 & 65.5 & 18 & 11 & $"$ \\
\hline 3671 & Arisan & 15. ix. 1918 & oad. & 77.5 & 63.5 & 18 & 10.5 & $"$ \\
\hline 3672 & Nokozan & 17. " & qjuv. & 80 & 70.5 & 18 & 10.5 & $"$ \\
\hline 3673 & $"$ & 18. " & gad. & 79 & 68 & 18.5 & 10 & " \\
\hline 4519 & $" \prime$ & 22. v. 1920 & qad. & 78 & 66 & 18 & 10.5 & $"$ \\
\hline
\end{tabular}

My adult male specimens have their sides of the breast only washed or patched with reddish orange, exactly like the original description of Messrs. Rothschild and Hartert. Poasibly Marquis Yamashina (see his Japanese description) is quite right to consider that the reddish patch is variable according to the individual and would not have colour phases as in the cases of $P$. pyrihula griseiventris.

No. 3672 in my collection is a juvenile female which has the crown and nape uniform duller brown, the chin duller greyish black and the breast and flanks paler than the adult females before me.

\section{Pyrrhula nipalensis uchidai.}

1912.-Pyrrhula owstoni(nec Rothschild \& Hartert), Uchida, Annot. Zool. Japon., viii, pt. 1, p. 203(Shishaban, Banshoryô Distr., July 16). 1912.-Pyrhula owstoni(nec Rothschild \& Hartert), Ogilvie-Grant, Ibis, p. 644.

1915.-Pyrrtula owstoni (nec Rothschild \& Hartert), Uchida, Birds of Japan, Suppl., p. 98, Oct. 4, 1915(Arisan). (In Japanese.)

1916. - Pyrrhula uehidai Kuroda, Dôbutsugaku Zasshi, xxviii, p. 265, July 15, 1916(Shishaban, Akô Distr.- đ ㅇ, July 16, 1909, K. Kikuchi coll.). (In Japanese.) Berlin.

* Exchanged with a different species of bird by the Zoological Museum, 
1917.-Pyrrhula uchidai Kuroda, Annot. Zool. Japon., ix, pt. 3, p. 295 (Shishaban, Akô Distr.).

1919.-Pyrrhala uchidai Kuroda, Hartert, Nov. Zool., xxvi, p. 160 (as a young of owstoni).

1928.-Pyrrhula uchidai Kuroda, Tori, vi, no. 26, p. 9 (as a young of owstoni). (In Japanese.)

1932.-Pyrrhula uchidai Kuroda, Hand-L. Jap. Bds., p. 13 (as a young of oustoni).

Mr. T. Kazano of Formosa has recently collected two pairs of uchidai on Mt. Arisan and has sent me one of the females for identification. It mea sures as follows: + ad, Kazano's coll. no.34, Numano-taira on Mt. Arisan, 13. vi. 1935 , wing 85.5 , tail 72 , central rectrices 51 , tarsus 16.5 , exposed culmen $10.5 \mathrm{~mm}$.

Mr. Kazano has informed me that uchidai and owstoni are usunlly found in different groups in the wild state. But they may be in a company together sometimes as already stated by some authors.

I am glad to publish a coloured plate which contains my type male and paratype female of uchidai from Shishaban, Akô District (now in Takao-siu) as the Plate $I$ of this number of "Tori." The plate was drawn by Mr. K. Yokoyama in 1916*

A longitudinal white patch on the central rectrices is one of the definite characteristics of this form; not a partial albinism as considered by Dr. Hartert (Nov. Zool., xxvi, p. 161, 1919). For, Marquis Yamashina has found it in all specimens $(27 \delta q)$ and none of the specimens have uniform central rectrices!

There are 4 forms of erythaca-group and 5 of nipalensis-group which have been known to science. They are listed and annotated below:

\section{Pyrrhula erythaca-group.}

1. Pyrrhula erythaca erythaca Blyth. Beavan's Bullfinch.

1862.-Pyrrhula enythacaBlyth, Ibis, p. 389(Sikkim).

* A coloured figure of an adult male of $P$. erythaca owstoni is appeared in the plate 11, fig. 87 of Kuroda's "Birds in Life Colours," Vol, I(1933). 
Distr. "Sikkim, Bhutan and the hills North of the Brahmaputra" (S. Baker).

2. Pyrrhula erythaca altera Rippon. Rippon's Bullfinch.

1906.-Pyrhulu altera Rippon, Bull. B.O.C., xix, p.19(W.Yunnan). Distr. Yunnan and Shan States.

3. Pyrrhula erythaca owstoni Rothschild \& Hartert. Formosan Bullfinch.

1907.-See anteà.

Distr. Confined to the mountains of Formosa.

4. Pyrrhula erythaca wilderi Riley. Wilder's Bullfinch.

1918.- Pyrmula erythaca wideri Riley, Proc. Biol. Soc. Washington,

Vol. 31, p. 33, May 16, 1918 (Eastern Hills about sixty miles cast of Peking, China- + ad, Feb., 1917).

1921.-Pyrhula erythaca taipaishanensis Rothschild, Nov. Zool., xxviii, p. 63(Tai-pai-shan, Tsin-ling Mts., China).

Distr. China: "Chihli (winter. resident ?). Shensi (resident)" (La Touche).

\section{Pyrrhula nipalensis-group.}

1. Pyrrhula nipalensis nipalensis Hodgson. Brown Bullfinch. 1836.-Pyprthula nipalensis Hodgson, Asiat. Res., xix, p. 155(Nepal). Distr. "The Himalayns from Gilgit to Eastern Assam" (S. Baker).

2. Pyrrhula nipalensis victoriæ Rippon. Mount Victoria Bullfinch. 1906.-Pyrrhula victorix Rippon, Bull. B. O. C., xvi, p. 47 (Mt. Victoria, Chin Hills).

Distr. "At present known only from Mt. Victorin and adjoining hills"(S. Baker).

8. Pyrrhula nipalensis waterstradti Hartert. Malay Bullfinch. 1902.-Pyrrhula waterstradti Hartert, Bull. B. O. C., xii, p. 69, April 28, 1902 (Mt. Tahang, 5000-7000 feet, Eastern Malay Peninsula, Oct., 1901),

Distr. "The mountains of Perak, Selangor and Pahang, never below an elevation of 4500 feet" (Robinson). 
4. Pyrrhula nipalensis ricketti La Touche. Fohkien Bullfinch. 1905.-Pyrrhula ricketti La Touche, Bull. B. O. C., xvi, p. 21, Nov. 1, 1905(mountains of N. W. Fohkien, S. E. China).

Distr. S. E. China: 'N. W. Fohkien (resident). N. E. Kwangtung (resident?)" (La Touche).

Mr. Stuart Baker says that "birds from these parts seem hardly separable [from nipalensis] though they are perhaps a trifle darker."

5. Pyrrhla nipalensis uchida Kuroda. Uchida's Bullfinch.

1916.-See anteà.

Distr. Confined to the mountains of Formosa.

I have examined some skins of owstoni (with so-called "arizanica"), wilderi ( 3 examples in my collection), waterstradti (examined in the Raffles Museum, Singapore), ricketti (examined in the Tring and Shanghai Museums) and uchidai; but $\mathrm{I}$ have not yet seen typical enythaca, altera and typical nipalensis and victorix. Although $I$ am in the above circumstances, I have made out an artificial key for the forms of enythaca and nipalensis which would be of some use for reference. This key, however, is carefully made out by making use of the descriptions of all the forms; and what has thus finally been arrived at is the following conclusive key.

Key to species and subspecies of erythaca and nipalensis.

$\left\{\begin{array}{l}\text { Feathers round the base of bill velvety black; innermost tertiary } \\ \text { not edged with red or yellow on the outer web (species } \\ \text { erythaca) ….................................................... } \\ \text { Feathers round the bese of bill brown or greyish-brown; inner- } \\ \text { most tertiary edged with red }(\delta) \text { or yellow }(q) \text { on the } \\ \text { outer web (species nipalensis) …............................... }\end{array}\right.$

(Breast, upper abdomen and flanks orange-red in males; back greyer in females..................................................

2 Sides of breast faintly washed with rosy-red or breast (rarely?) paler orange-red in males; back and underparts dull rufousbrown in females ................................erythaca owstoni.

(Orange-red of underparts paler; a broad black band round the base of bill; white on the forehead narrower; females duller 


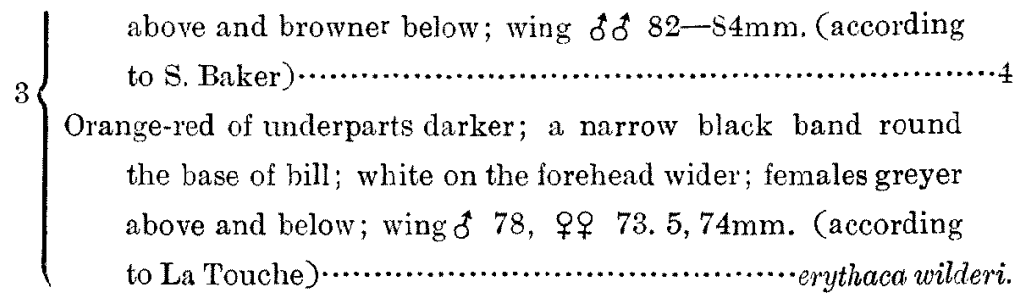

$4\left\{\begin{array}{c}\text { Upper parts paler grey; breast paler red in males, paler brown } \\ \text { in females.........................................erythaca erythaca. } \\ \text { Upper parts darker grey; breast deeper and richer red in males, } \\ \text { darker and more brown in females ................erythaca altera. }\end{array}\right.$

(Central rectrices always with a distinct central streak of white in both sexes ....................................nipalensis uchidai.

5 Central rectrices metallic bronze; a white patch under the eye

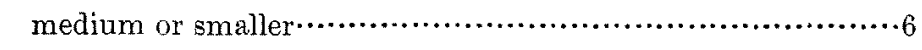

Central rectrices metallic purplish; a white patch under the eye much larger.................................nipalensis waterstradti.

Crown and nape blackish brown, each feather margined with light ashy-brown; a white patch under the eye in both sexes

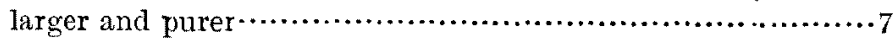

6 Crown and nape grey-brown, subterminally blackish-brown, each feather margined with pale grey-brown; a white patch under the eye in both sexes smaller and duller........nipalensis ricketti. $7\{$ Above ashy-brown tinged with chocolate colour $\cdots$ nipalensis nipalensis. (Above greyer, less tinged with chocolate colour...nipalensis victorix. Principal literature not cited above.

1926.-Stuart Baker; Fauna of British India, Birds, iii, pp. 109, 111114, March, 1926.

1927.-La Touche: A Handbook of the Birds of Eastern China, i, pt. iv, pp. 307-310, Aug., 1927,

1928.-Robinson: The Birds of the Malay Peninsula, ii, pp. 268-269, pl. $23[P$. n. waterstradti], July, 1928.

1930.-Stuart Baker: Faun. Brit.. Ind., Bds.,vii, p. 227, March, 1930.

1935.- Yamashina, Marquis : On Pyrrhula uchidai and $P$. owstoni. "Tori," vol. ix, no. 41, pp. 1-6. (In Japanese.) 
"TORI" VOL. IX, PL. I.

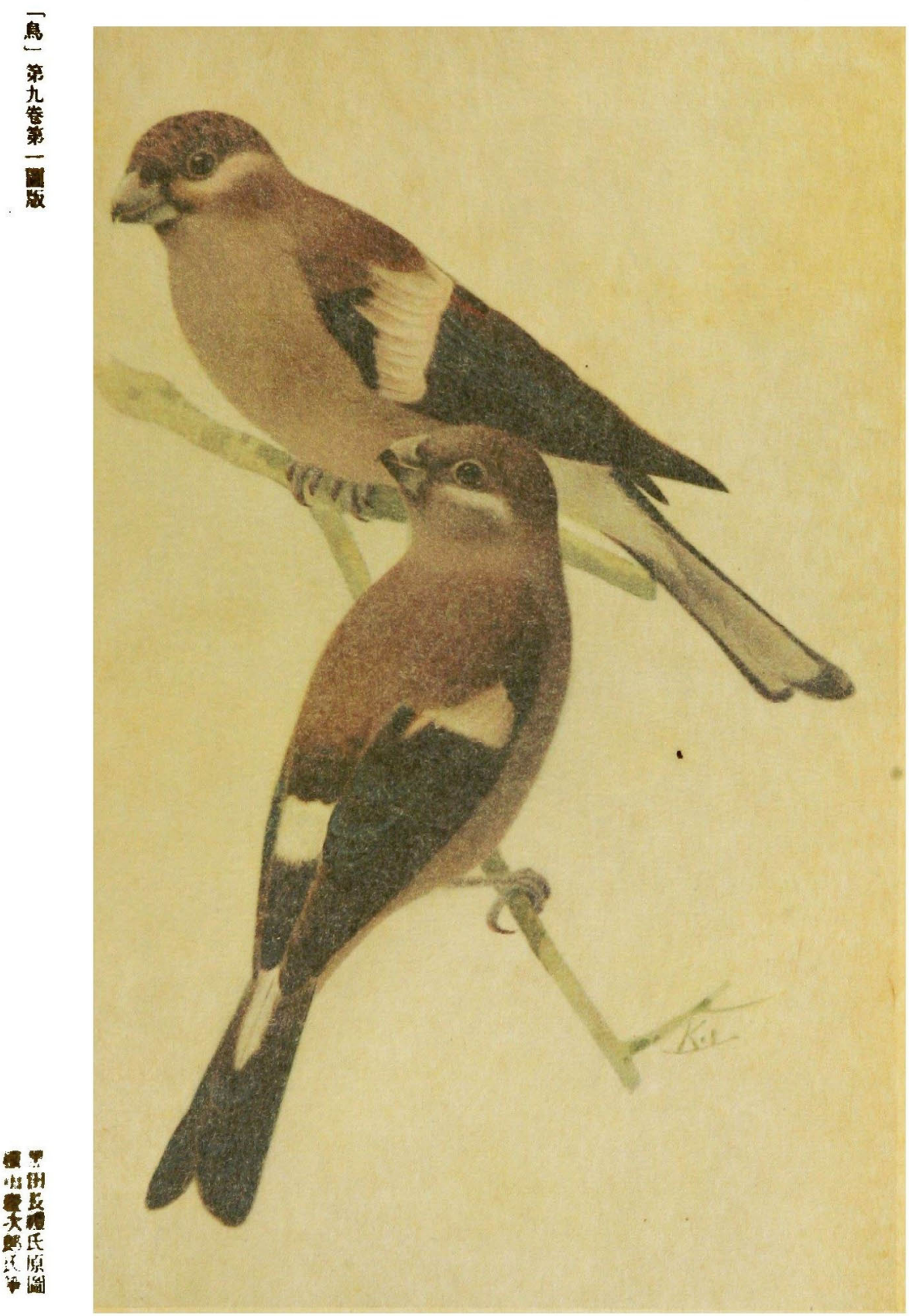

臺湭產ウチダウン此（下）雄（上）

A pair of Pyrrhula nipalens is uchidai Kuroda of Formosa. $7 / 8$ nat. size. 
"TORI", VOL. IX, PL. I.

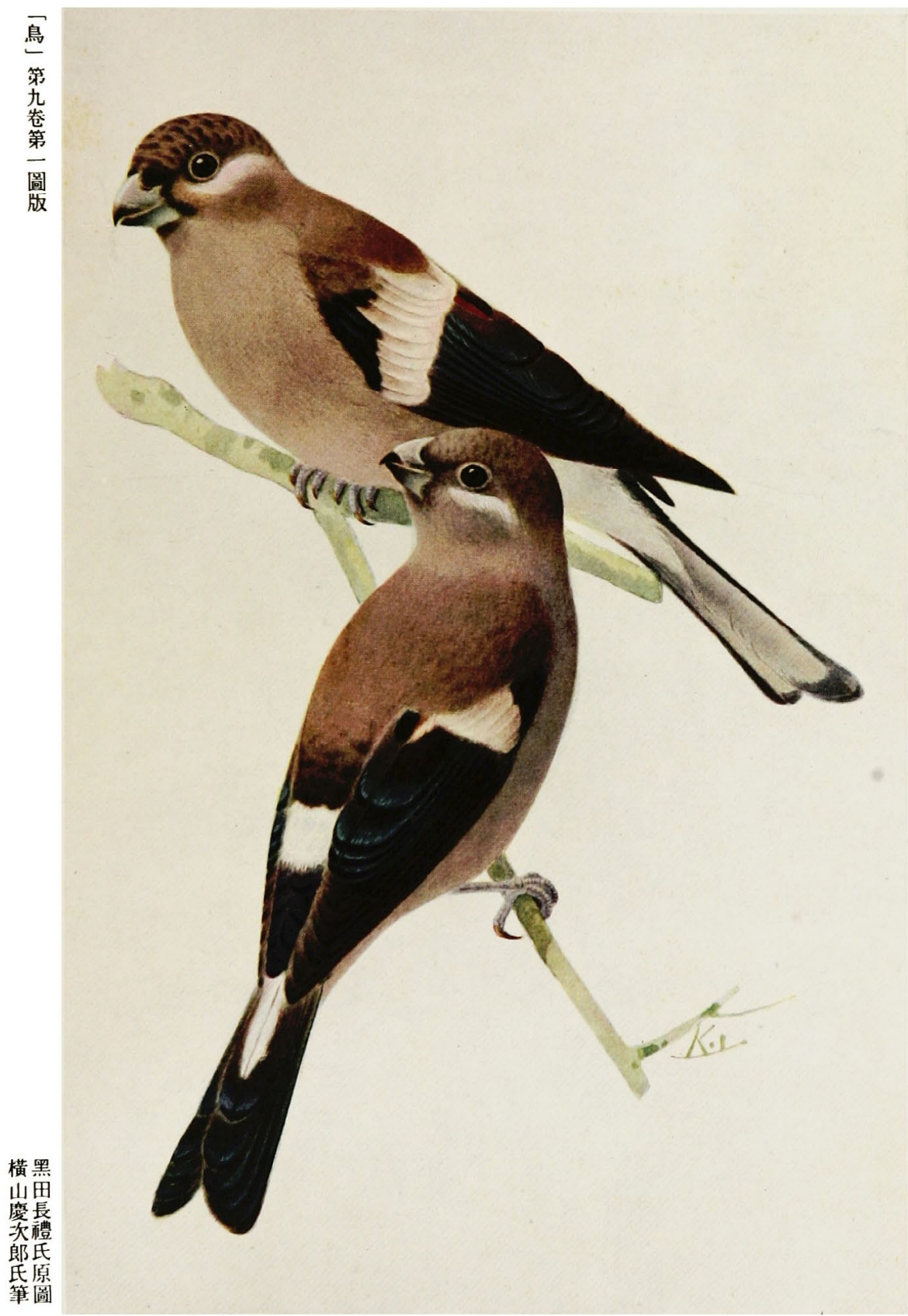

堂灣產ウチダウソ雌（下）雄（上）

A pair of Pyrrhula nipalensis uchidai Kuroda of Formosa. $7 / 8$ nat. size. 